\title{
CD34+ and CD133+ Primitive Stem Cell Expression in Peripheral Blood: Considering Gender, Age, and Smoking
}

\author{
Heike Reichelt Dagmar Barz Hansjörg Thude \\ University Hospital of Jena, Institute for Transfusion Medicine, Jena, Germany
}

\section{Key Words \\ Primitive progenitor cells $\cdot$ CD34+ $\cdot$ CD133+ $\cdot$ Gender . Age $\cdot$ Smoking}

\section{Summary}

Background: The number of primitive progenitor cells (pPC) in healthy individuals, in correlation to age, gender, and smoking status, has not yet been thoroughly elucidated. Material and Methods: The pPC from a collective of 168 healthy blood donors aged 18-61 years was investigated using flow cytometric analysis. In addition, the pPC of 20 subjects were studied once a month for half a year to determine the extent of physiological variation of $\mathrm{pPC}$ within a single individual. Results: We demonstrated a statistically significant difference $(p=$ $0.005)$ in the numbers of pPC in men $(836,100 / l)$ versus women $(583,850 / 1)$. No statistical difference was found between younger and older donors or between smokers and non-smokers, both overall and within a single gender. The extent of physiological variation in pPC was lower than $20 \%$ in 2 individuals, 18 individuals exhibited amplitudes greater than $20 \%$. Conclusion: We conclude that the number of pPC in healthy individuals was primarily determined by gender as an operative factor. It seems that age and smoking status are of minor importance. Furthermore, our data demonstrate strong variability in the expression of pPC within a single individual. This may be influenced by varying physiological and environmental factors.

\author{
Schlüsselwörter \\ Primitive Stammzellen - CD34+ · CD133+ · Geschlecht . \\ Alter · Rauchen
}

\section{Zusammenfassung}

Hintergrund: Die Anzahl primitiver Stammzellen (pPC) im peripheren Blut gesunder Personen bezogen auf $\mathrm{Ge}-$ schlecht, Alter und Raucherstatus wurde bisher nicht evaluiert. Material und Methoden: Die primitiven Stammzellen eines gesunden Kollektives von 168 Blutspendern in einem Alter von 18-61 Jahren wurden mittels Durchflusszytometrie untersucht. Zusätzlich wurden die pPC von 20 Personen über einen Zeitraum von einem halben Jahr monatlich gemessen, um die physiologische Variationsbreite von pPC innerhalb eines Individuums zu erfassen. Ergebnisse: Es konnte ein statistisch signifikanter Unterschied ( $p=0,005)$ in der Anzahl von pPC bei Männern (836 100/l) gegenüber Frauen (583 850/l) gemessen werden. Kein statistisch signifikanter Unterschied fand sich zwischen jungen und alten Spendern, Rauchern und Nichtrauchern - gemessen sowohl über alle Spender als auch innerhalb eines Geschlechtes. Das Ausmaß physiologischer Variation von pPC war in 2 Personen kleiner als $20 \%$, bei 18 Personen größer als $20 \%$. Schlussfolgerung: Es wurde festgestellt, dass die Anzahl von pPC in gesunden Individuen primär geschlechtsabhängig ist. Es scheint, dass Alter und Raucherstatus keinen Einfluss haben. Außerdem demonstrieren die Daten hohe Variabilität innerhalb eines Individuums. Dies mag durch eine Vielzahl physiologischer und umweltbedingter Faktoren bedingt sein.

\begin{tabular}{ll}
\hline KARGER & ( 2009 S. Karger GmbH, Freiburg \\
$\begin{array}{l}\text { Fax }+497614520714 \\
\text { Information@Karger.de } \\
\text { www.karger.com }\end{array}$ & $\begin{array}{l}\text { Accessible online at: } \\
\text { www.karger.com/tmh }\end{array}$
\end{tabular}




\section{Introduction}

Stem cells are undifferentiated and unspecialized systemic cells characterized by nearly unrestricted self-renewal by successive divisions. These cells originate from a clone of which descendants can differentiate and give rise to specialized cells enabling the potential to repair damaged tissue or replace it. Surface molecules are utilized to identify stem cells. One important marker is the CD34 antigen expressed on most stem cells [1]. Further molecules characterize different subpopulations of stem cells. The CD133 antigen belongs to this group. The CD133 antigen (formerly referred to as AC133) is a 120$\mathrm{kDa} 5$-transmembrane domain glycoprotein found on hematopoietic stem and progenitor cells $[2,3]$. In contrast to the CD34 antigen, the CD133 antigen is lost very early during the differentiation process. Thus CD133 is not detected on late progenitors such as pre-B cells, colony-forming unit erythrocytes, and colony-forming unit granulocytes. Combined expressions of CD34 and CD133 antigens point to a very immature population of strongly proliferating primitive progenitor cells (pPC). It is possible to detect pPC in very small numbers in peripheral venous blood [4-6]. This population includes the hemangioblast, a pluripotent stem cell which can differentiate into a hematopoietic stem cell and an endothelial progenitor cell [7-9]. PPC may also develop into cells of a variety of tissues including muscles, neurons, astrocytes, and oligodendrocytes, kidney proximal tubules, the parietal layer of Bowman's capsule of juxtamedullary nephrons, the lactiferous ducts of the mammary gland, as well as into cells of the prostate gland and the liver $[4,5,10-15]$. An increased presence of $\mathrm{pPC}$ is commonly associated with certain diseases. PPC have been detected with higher frequencies in intestinal cancer and cell lines of teratoma, retinoblastoma and leukemia, and in some illnesses of the hematopoietic cell lines (acute myeloid leukemia, acute lymphoblastic leukemia, chronic myelogenous leukemia, myelodysplastic syndrome) [2, 16-22].

Detailed information on expression of $\mathrm{pPC}$ in the peripheral blood of healthy individuals considering gender, age, and smoking status is lacking. Therefore, we have investigated pPC by flow cytometric analysis in a large collective of healthy individuals $(\mathrm{n}=168)$ with a broadly based aging structure and an evenly distributed smoking status. This study may provide new insight into cell regeneration resulted from $\mathrm{pPC}$ in healthy individuals correlating to gender, age, and smoking status. In addition, the extent to which $\mathrm{pPC}$ varies within a single individual remains unknown. We addressed this question and analyzed pPC in 20 subjects once monthly over a 6 month period by flow cytometric analysis.

\section{Material and Methods}

Characteristics of Study Participants

A total of 168 healthy blood donors (92 male and 76 female) were included in the study. Participants were recruited from the Institute of Transfu-
Table 1. Distribution of smoking over all study participants

\begin{tabular}{llllll}
\hline \multirow{2}{*}{ Age, years } & \multicolumn{2}{l}{ Male $^{\mathrm{a}}$} & & & \multicolumn{2}{l}{ Female $^{\mathrm{a}}$} & \\
\cline { 2 - 3 } \cline { 5 - 6 } & smoker & non-smoker & & smoker & non-smoker \\
& & & & & \\
\hline $18-29$ & 11 & 18 & & 12 & 11 \\
$30-39$ & 12 & 13 & & 5 & 13 \\
$40-49$ & 10 & 12 & 4 & 9 \\
$50-61$ & 4 & 12 & & & 13 \\
\hline
\end{tabular}

${ }^{a}$ On average, women smoked 9.4 cigarettes per day (range 2-20) and men smoked 11.6 cigarettes per day (range 2-30).

sion Medicine in Jena. Informed consent was obtained from all subjects. None were treated with drugs (contraceptives were exempt), and all had normal blood cell counts, normal blood pressure, and did not suffer from diabetes, cancer, hypercholesterolemia, or hyperlipidemia. The mean age at the time of analysis was 37 (range 18-61) years. 37 men (40\%) and 33 women $(43 \%)$ were smokers, and 98 individuals were non-smokers. The distribution of smoking for male and female in each age group is shown in table 1. On average, women smoked 9.4 cigarettes per day (range 2-20) and men smoked 11.6 cigarettes per day (range 2-30).

\section{Blood Count}

A $150-\mu$ EDTA anticoagulated blood sample was used to take a complete blood count with the Cell-Dyn 4000 (Abott, Wiesbaden, Germany). Total numbers of leukocytes, red blood cells, hemoglobin, hematocrit, mean corpuscular volume (MCV), mean corpuscular hemoglobin $(\mathrm{MCH}), \mathrm{MCH}$ concentration (MCHC), platelets, neutrophil granulocytes, lymphocytes, monocytes, eosinophil, and basophil granulocytes were counted.

\section{Flow Cytometric Analysis}

In each case, blood count and flow cytometric analysis were determined from the same blood sample. Flow cytometric measurements were performed on a FACS Calibur flow cytometer (Becton Dickinson, Heidelberg, Germany) using a two-color analysis applying anti-human CD34FITC (clone: 581; this antibody reacts with class III of CD34 epitope; BD Pharmingen, Heidelberg, Germany) and anti-human CD133/2-PE (clone: 293C3; Miltenyi Biotec, Bergisch Gladbach, Germany) antibodies. In detail, $4.5 \mathrm{ml}$ of peripheral venous blood anticoagulated with EDTA were taken to identify circulating pPC. First, red blood cells were lysed twice for $12 \mathrm{~min}$ at room temperature with FACS Lysing Solution (Becton Dickinson). Afterwards, the cells were washed with PBS (Sigma, Taufkirchen, Germany). To avoid Fc receptor-mediated labeling, $20 \mu \mathrm{l}$ FCR Blocking Reagent (Miltenyi Biotec) was used to block Fc receptors. Cells were incubated for $8 \mathrm{~min}$ in the dark at $8{ }^{\circ} \mathrm{C}$ and washed twice with PBS. Afterwards, pPC were labeled with $10 \mu$ anti human CD34-FITC antibody and $10 \mu \mathrm{l}$ 1:5 diluted anti-human CD133/2-PE antibody and incubated for $12 \mathrm{~min}$ in the dark at $8{ }^{\circ} \mathrm{C}$. $10 \mu \mathrm{l}$ FITC-Mouse $\operatorname{IgG}_{1}, \kappa(\mathrm{BD}$ Pharmingen) and $10 \mu \mathrm{l}$ 1:5 diluted PE-Mouse $\operatorname{IgG}_{2 \mathrm{~b}}$, $\kappa$ (Becton Dickinson) antibodies served as isotype-specific controls in each measurement. Then, the incubation cells were washed twice with PBS and resuspended in $500 \mu \mathrm{l}$ of PBS. Analysis was performed after setting an individual live gate for each sample on lymphocytes in the dot plot using forward and sideward scatter characteristics (fig. 1 A). In this gate, 200,000 events were counted. In each plot, isotype control and cell count quadrants were set at $10^{1}$ to determine positive and negative cells. If the isotype control showed positive counts in the upper right quadrant, the measurement was rejected and not included in the study in case of unspecific labeling. Data were analyzed by Cellquest Pro Software (Becton Dickinson). The exact number of circulating pPC per liter of peripheral venous blood was calcu- 
Fig. 1. Circulating pPCs from peripheral venous blood were identified by two-color flow cytometric analyses. A Lymphocytes were gated by forward/sideward scatter characteristics. B Isotype control, gated lymphocytes were labeled with FITC-Mouse-IgG $\mathrm{I}_{1}, \mathrm{~K}$ and PE-Mouse- $\operatorname{IgG}_{2 b}$, $\kappa$. Gated lymphocytes were stained with CD34-FITC and CD133/2-PE antibodies. C Circulating CD34+/CD133+ pPC are found in the upper right quadrant.
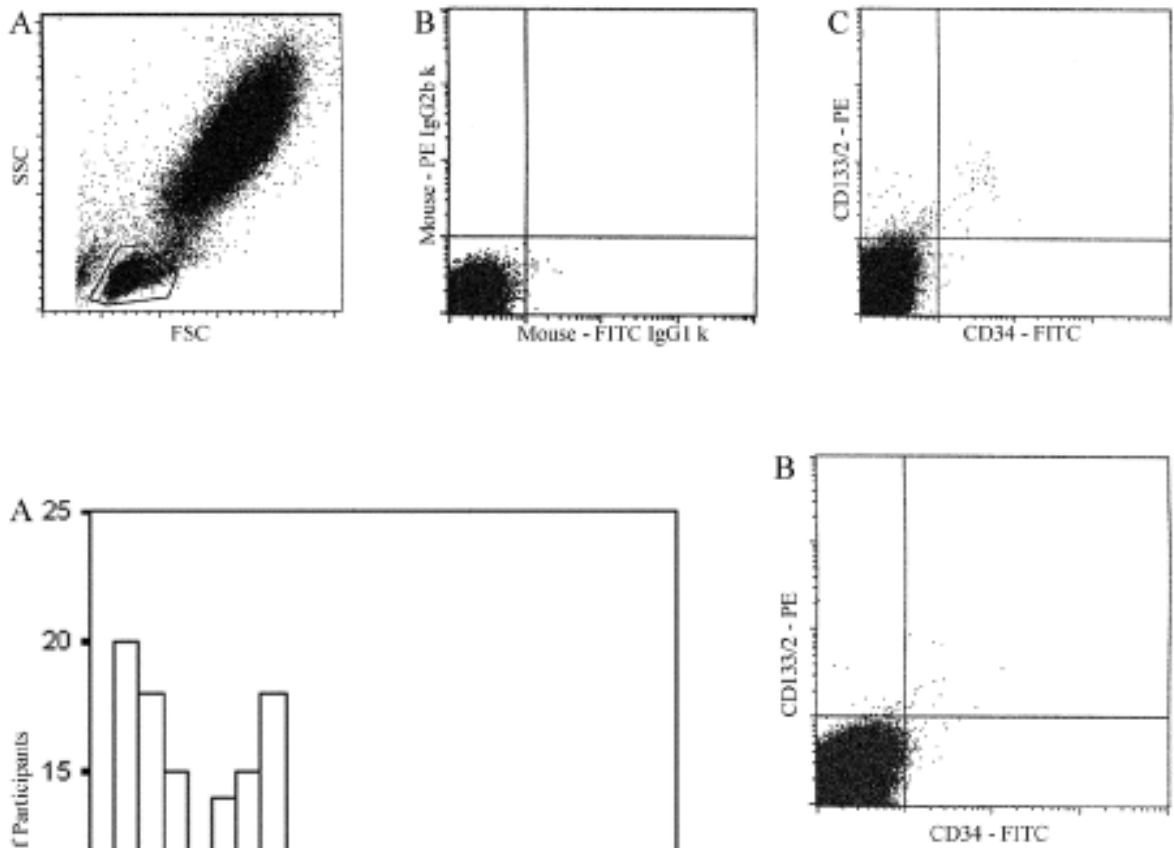

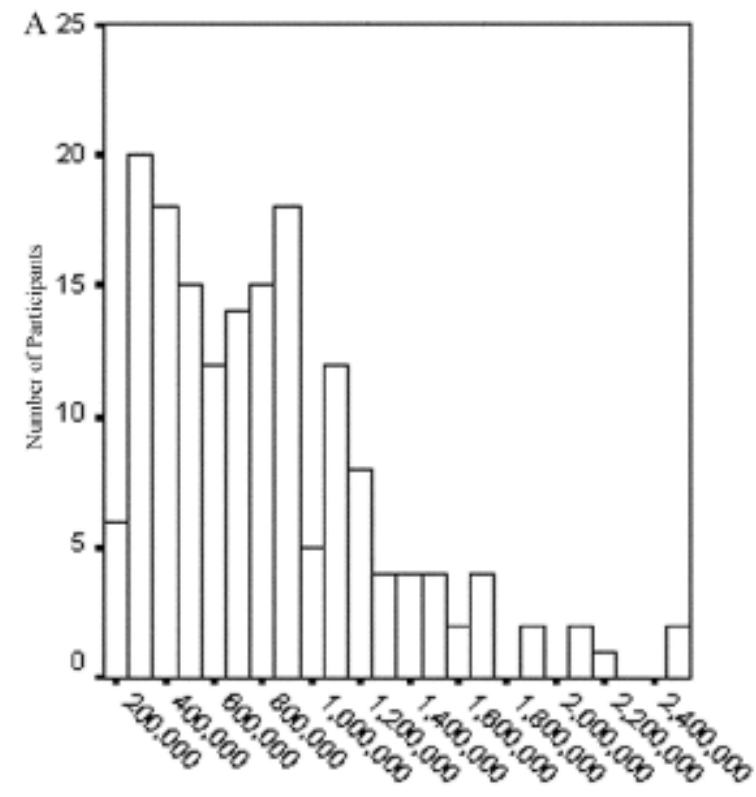

PPC per liter peripheral blood

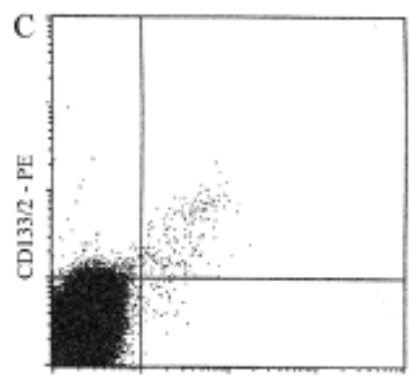

CD34 - FTTC plots.

lated using the mathematical correlation (rule of three) between counted lymphocytes per liter blood from donor and the CD34+/CD133+ number of 200,000 counted lymphocytes in the flow cytometric analysis. To define a valid analysis, a minimum number of detected CD34+/CD133+ cells was not fixed.

\section{Statistical Analysis}

All statistical analyses were performed using the computer software SPSS for Windows, version 11.5 (SPSS Inc, Chicago, IL, USA). The Kolmogorov-Smirnov test was used to determine either normal or nonnormal data distribution. Test results showed a non-normal curve of distribution. To determine statistical significance, the nonparametric MannWhitney-U test was applied. The exact two-sided values of $\mathrm{p}<0.05$ were interpreted to denote statistical significance. For more than 2 samples, the Kruskal-Wallis test was used to determine statistical significance. In these cases, $\mathrm{p}$ was calculated as having an asymptotic significance. All data are presented as median.

\section{Results}

Two-color flow cytometric analysis was applied for identification of pPC in the peripheral blood of healthy blood donors. A total of 253 flow cytometric analyses were performed. Four examples were rejected, described by the criteria in Material and Methods. A representative result is shown in figure 1. Dot plot C of figure 1 displays CD34+ and CD133+ pPC as a small distinct population within the lymphocytes. This technique of flow cytometric analysis appeared to be reproducible, because 4 distinct approaches of the same blood probe gave nearly same amounts of pPC (standard deviation of 7\%). Therefore, we performed this kind of flow cytometric analysis for each individual enrolled in the study $(\mathrm{n}=168)$. The distribution of pPC per liter over all participants is summarized in figure 2 A. Most subjects showed pPC counts between 300,000 and 900,000 cells per liter blood. For all donors, a median blood level of circulating pPC was determined to be about 732,725 cells per liter blood. The lowest measured level was 159,510 pPC per liter blood for a 33-year-old male participant who smokes 15 cigarettes per day (fig. 2B). The highest measured level was 2,540,000 pPC per liter blood for a 54-year-old male participant who also smokes 15 cigarettes per day (fig. 2C).

Circulating pPCs were also calculated in proportion to CD34+ cells, lymphocytes, and leukocytes. Some donors simultaneously showed high absolute numbers of $\mathrm{pPC}$ at low levels of CD34+ cells and lymphocytes, other donors showed low absolute numbers of pPC at high levels of CD34+ cells 


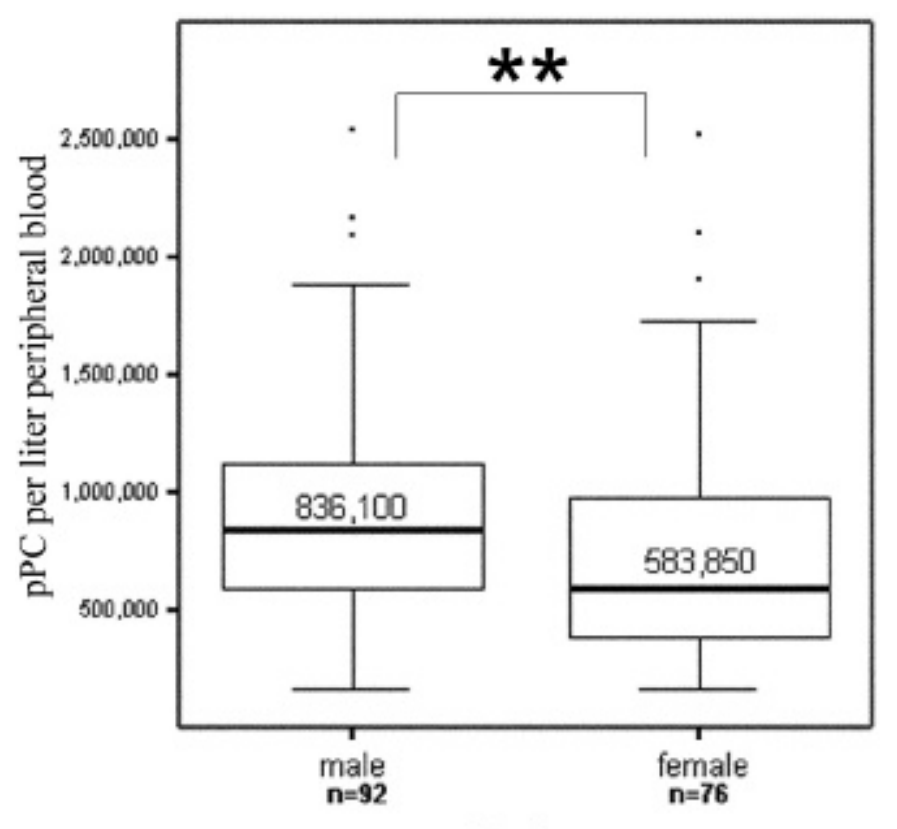

Gender

Fig. 3. Average number of pPC per liter blood in male and female participants investigated by flow cytometric analysis. $\mathrm{n}=$ number of participants in each group. $* * \mathrm{p}=0.005$ by Whitney $\mathrm{U}$ test.

and middle or high levels of lymphocytes (data not shown). In detail, the description of pPC as a percentage of CD34+ cells, from lymphocytes, and from leukocytes leads to mean values of about $68,0.05$, and 0.02 , respectively.

Data from flow cytometric analysis were utilized to determine the distribution of pPC dependent on gender. Blood of male individuals contained an average of 836,100 pPC per liter blood. In contrast, a value of $583,850 \mathrm{pPC}$ per liter blood was determined for female individuals (fig. 3). This difference is statistically most significant $(\mathrm{p}=0.005)$.

No significant statistical difference was found between younger and older donors $(p=0.97)$ and between smokers and non-smokers $(\mathrm{p}=0.31)$, not only overall but also within a single gender (data not shown). The Kruskal-Wallis test resulted in age-related differences within a single gender showing a non-significant statistical value of about $p=0.52$ for males and $p=0.47$ for females. The same test was used to determine smoking-related differences within one gender. Statistical values of $p=0.63$ for male and $p=0.38$ for female individuals were found, demonstrating no significance. In addition, no statistical difference was detected between women with and without oral contraceptives ( $\mathrm{p}=0.38$; data not shown).

To quantify the extent of long-term variation of circulating pPC in the blood of healthy individuals, 10 male and 10 female donors were investigated over a period of 6 months. Most donors were measured once per month. The variation of pPC level is shown for each participant in figure 4. In summary, 2 donors had a variation of less than $20 \%, 11$ donors demonstrated a variation between 20 and $60 \%, 4$ donors var- ied between 60 and $120 \%$, and 3 donors varied over $120 \%$. The highest level of variation was $321 \%$ from a 33 -years-old chronic male smoker. No correlation was found between variation of pPC levels and gender, smoking status, time of day, or variation in donor time (data not shown).

\section{Discussion}

Different approaches have been developed for the quantification of stem cells, progenitor cells, and stem cell subpopulations. Often, stem cells are isolated and enriched from peripheral blood by immunomagnetic beads. Afterwards, a cultivation step follows in order to quantify stem cells by counting the colony-forming units. In this approach, the artificial cultivation conditions may modify the expression of surface molecules and produce a selection pressure resulting in inaccurate stem cell quantification. To avoid such problems, we preferred a direct determination of CD34+/CD133+ pPC in peripheral blood by flow cytometric analysis. Thereby, we obtained a mean value of 732,725 pPC per liter blood for our investigated collective of healthy blood donors $(\mathrm{n}=168)$. Furthermore, our results demonstrate that $68 \%$ of CD $34+$ stem cells, $0.05 \%$ of lymphocytes, and $0.02 \%$ of leukocytes belong to the CD34+/CD133+ stem cell subpopulation named pPC. A more thorough assessment of these data remains problematic, as only one published study from Kondo et al. [23] has provided a numerical value for pPC in peripheral blood. In addition, this study only involved a small number of male subjects. They found a value of approximately 1,000,000 $\mathrm{pPC}$ per liter blood for non-smokers $(\mathrm{n}=14)$ and nearly $700,000 \mathrm{pPC}$ for smokers $(\mathrm{n}=15)$, resulting in a mean value of $850,000 \mathrm{pPC}$ per liter blood for the entire collective. The difference in the values for pPC may arise from the number of investigated individuals and the exclusion of women. Furthermore, flow cytometric analysis was performed with various $\mathrm{CD} 34$ antibodies, which may cause the difference for $\mathrm{pPC}$ per liter blood in both studies.

We obtained a value of 836,100 pPC per liter blood in males and 583,850 pPC per liter blood in females. This difference was statistically highly significant $(\mathrm{p}=0.005)$, but should be proofed in the future by more sophisticated fluorescenceactivated cell sorting (FACS) analysis concepts. Nevertheless, our data indicate a pronounced difference in the regeneration capacity between males and females, based on pPC. However, this assumption may only be made if the functional properties of pPC in the male and females individuals are homogenous. Unfortunately, we did not perform functional assays to test for this hypothesis. The question remains as to what is the cause of the observed difference in the number of pPC per liter blood between female and male individuals. It is conceivable that the difference may be caused by hormones, in particular sexual hormones. One anabolic effect of testosterone in healthy male individuals is a larger body constitution as compared to healthy female individuals. Recently, estrogen and 

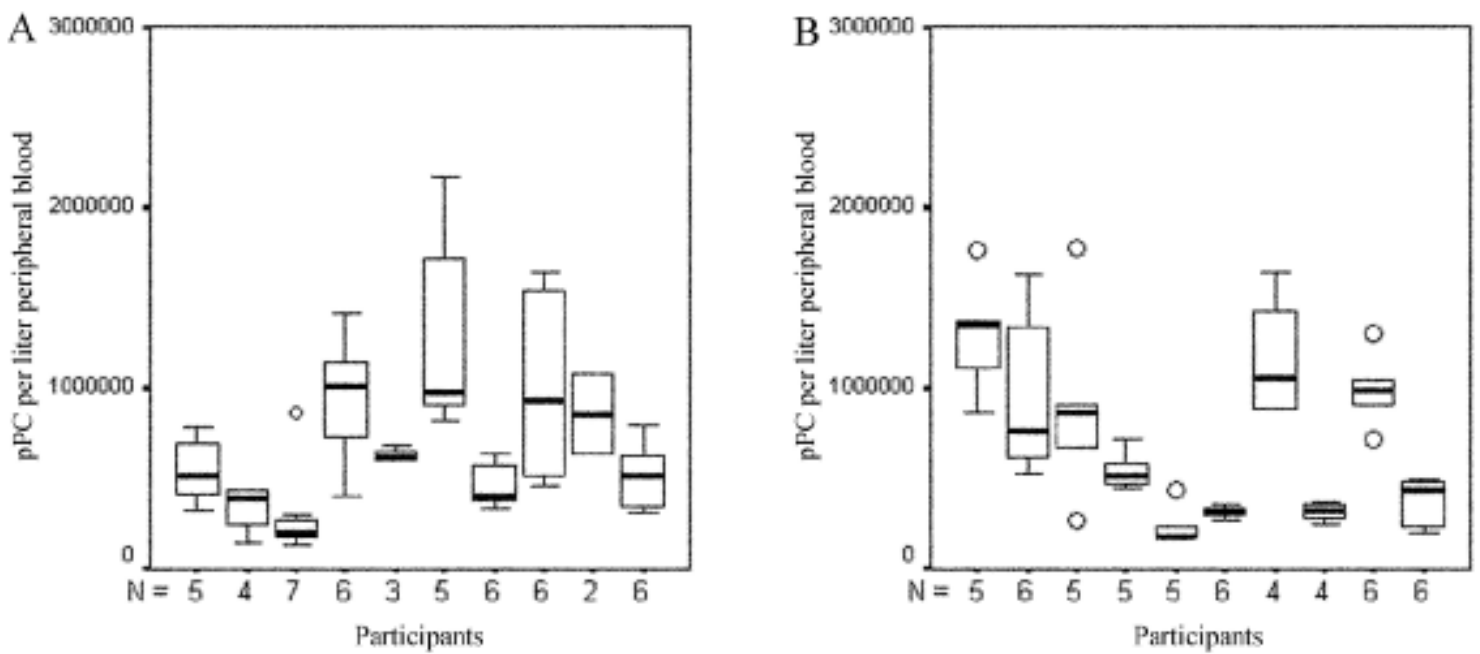

progesterone receptors were found on the surface of human embryonic stem cells, permitting an interaction between sexual hormones and stem cells [24, 25]. Perhaps the interaction between the sexual hormone testosterone provides a higher mobilization rate for $\mathrm{pPC}$ in male individuals. This connection seems highly plausible physiologically, it may then be suggested that the capacity for regeneration resulting from $\mathrm{pPC}$ has been adapted to the body constitution. Nevertheless, this aspect should be evaluated by further studies.

The detected difference in the amount of pPC per liter blood in male and female individuals assumes greater importance when considered from the clinical perspective. One critical factor for success of allogenic stem cell transplantation is the yield of stem cells including pPC obtained from the donor. The greater number of $\mathrm{pPC}$ per liter blood in male individuals leads to the suggestion that a male individual is a more suitable stem cell donor than a female. Our suggestion is in line with published data from Pulsipher et al. [26], predicting an increased yield of CD34+ cell $/ \mathrm{kg}$ donor weight collected from male individuals. But it should be noted that this statement presumes homogenous functional properties of $\mathrm{pPC}$ in male and female individuals.

In contrast to the study by Shaffer et al. [27], our results show that in both men and women the amount of pPC in peripheral blood is independent of age. The preliminary study of Shaffer et al. comprises only 22 healthy individuals. We investigated a greater collective thereby obtaining more predicative data. Further studies considered the influence of age on the amount of circulating endothelial progenitor cells (cEPC), a subpopulation of $\mathrm{pPC}$, in the peripheral blood of healthy individuals and also showed no correlation, whereas Tao et al. [28] found a dependence on age in men [29-31]. Two studies demonstrated a statistically significant reduction of circulating CD34+ cells in males of advancing age but not in females [32, 33]. A comparison of the results of our study and results of the studies mentioned above, which analyzed CD34+ stem cells or the cEPC subpopulation, is problematic as our investigation focused primarily on pPC. In general, the data reaffirms that the correlation between age and amount of stem cells is controversial, and any investigation must take into account the type of stem cell.

Smoking is an evident risk factor for a lot of widespread diseases like chronic obstructive pulmonary disease or arteriosclerosis causing myocardial infarction, peripheral arterial occlusive disease or stroke. The aim of our comparative analysis of smokers and non-smokers was to answer the question if smoking influence the number of progenitor cells thereby influencing the ability of tissue repair. We detected no correlation in the number of pPC per liter blood and smoking status in healthy individuals. Therefore, our study indicates that the mobilization rate of $\mathrm{pPC}$ was not influenced by this factor. Another study by Hill et al. [30] investigated the correlation between blood levels of EPC and smoking status. They also found no correlation supporting our data received for $\mathrm{pPC}$. In contrast, a study performed by Kondo et al. [23] observed in male individuals a sustained increase in the number of pPC and EPC, which was dependent on a cessation of smoking. After resumption of smoking, the number of $\mathrm{pPC}$ becomes equal to the level found before cessation. Further investigations are needed to clarify a connection between number of pPC per liter blood and smoking status.

Furthermore, we monitored the extent of variation in the number of pPC per liter blood in 20 healthy blood donors over a period of a half year. The unexpectedly high levels of variation suggest that the number of $\mathrm{pPC}$ in the peripheral blood of healthy individuals underlies substantial physiological variation. It is conceivable that mobilization of $\mathrm{pPC}$ into peripheral blood is individually controlled within each blood donor by different factors such as genetics, environmental, sport, stress, etc. The permanent interaction of such factors may result in the highly dynamic mobilization rates of pPC, which may explain the observed strong variation in the number of $\mathrm{pPC}$ per liter blood in a healthy individual. Widespread expression of stem cells is commonly used as a diagnostic marker to prognosticate risk for certain diseases, or as a marker to control the progress of a therapy. However, the use of pPC blood lev- 
els as a diagnostic marker appears limited because pPC levels in peripheral blood undergo such strong physiological variation within a single healthy individual. This aspect should be considered if the extent of pPC per liter blood is used as diagnostic marker.

In summary, our results have documented that pPC blood level strongly correlates to gender in healthy individuals. Age and smoking status do not influence the number of pPC blood in healthy individuals. In addition, we found strong variation in the number of $\mathrm{pPC}$ in peripheral blood within a single individual. This phenomenon may restrict use of pPC expression in peripheral blood as a tool for diagnostics. Overall, increased knowledge of pPC may offer increased potential and expanded possibilities for clinical benefits in the future.

\section{References}

1 Krause DS, Fackler MJ, Civin CI, May WS: CD34: Structure, biology, and clinical utility. Blood 1996; 87:1-13.

$>_{2}$ Yin AH, Miraglia S, Zanjani ED, Almeida-Porada G, Ogawa M, Leary AG, Olweus J, Kearney J, Buck DW: AC133, a novel marker for human hematopoietic stem and progenitor cells. Blood 1997;90:5002-12.

3 Miraglia S, Godfrey W, Yin AH, Atkins K, Warnke R, Holden JT, Bray RA, Waller EK, Buck DW: A novel five-transmembrane hematopoietic stem cell antigen: isolation, characterization, and molecular cloning. Blood 1997;90:5013-21.

4 Padovan CS, Jahn K, Birnbaum T, Reich P, Sostak P, Strupp M, Straube A: Expression of neuronal markers in differentiated marrow stromal cells and CD133+ stem-like cells. Cell Transplant 2003;12:839-48

5 Ratajczak MZ, Kucia M, Reca R, Majka M, Janowska-Wieczorek A, Ratajczak J: Stem cell plasticity revisited: CXCR4-positive cells expressing mRNA for early muscle, liver and neural cells 'hide out' in the bone marrow. Leukemia 2004:18:29-40.

6 Piechaczek C: Cd133. J Biol Regul Homeost Agents 2001;15:101-2.

7 Gehling UM, Ergun S, Schumacher U, Wagener C, Pantel K, Otte M, Schuch G, Schafhausen P, Mende T, Kilic N, Kluge K, Schafer B, Hossfeld DK, Fiedler W: In vitro differentiation of endothelial cells from AC133-positive progenitor cells. Blood 2000;95:3106-12.

8 Peichev M, Naiyer AJ, Pereira D, Zhu Z, Lane WJ, Williams M, Oz MC, Hicklin DJ, Witte L, Moore MA, Rafii S: Expression of VEGFR-2 and AC133 by circulating human CD34(+) cells identifies a population of functional endothelial precursors. Blood 2000;95:952-8.

$\checkmark$ Loges S, Fehse B, Brockmann MA, Lamszus K, Butzal M, Guckenbiehl M, Schuch G, Ergun S, Fischer U, Zander AR, Hossfeld DK, Fiedler W, Gehling UM: Identification of the adult human hemangioblast. Stem Cells Dev 2004;13:229-42.

10 Bhatia M: AC133 expression in human stem cells. Leukemia 2001;15:1685-8.

-11 De Wynter EA, Buck D, Hart C, Heywood R, Coutinho LH, Clayton A, Rafferty JA, Burt D, Guenechea G, Bueren JA, Gagen D, Fairbairn LJ, Lord BI, Testa NG: CD34+AC133+ cells isolated from cord blood are highly enriched in long-term culture-initiating cells, NOD/SCID-repopulating cells and dendritic cell progenitors. Stem Cells 1998;16:387-96.

12 Alessandri G, Pagano S, Bez A, Benetti A, Pozzi S, Iannolo $\mathrm{G}$, Baronio $\mathrm{M}$, Invernici $\mathrm{G}$, Caruso $\mathrm{A}, \mathrm{Mu}-$ neretto C, Bisleri G, Parati E: Isolation and culture of human muscle-derived stem cells able to differentiate into myogenic and neurogenic cell lineages. Lancet 2004;364:1872-83.
13 Hao HN, Zhao J, Thomas RL, Parker GC, Lyman WD: Fetal human hematopoietic stem cells can differentiate sequentially into neural stem cells and then astrocytes in vitro. J Hematother Stem Cell Res 2003;12:23-32.

14 Hemmati HD, Nakano I, Lazareff JA, Masterman-Smith M, Geschwind DH, Bronner-Fraser M, Kornblum HI: Cancerous stem cells can arise from pediatric brain tumors. Proc Natl Acad Sci U S A 2003;100:15178-83.

15 Florek M, Haase M, Marzesco AM, Freund D, Ehninger G, Huttner WB, Corbeil D: Prominin1/CD133, a neural and hematopoietic stem cell marker, is expressed in adult human differentiated cells and certain types of kidney cancer. Cell Tissue Res 2005;319:15-26.

16 Uchida N, Buck DW, He D, Reitsma MJ, Masek M, Phan TV, Tsukamoto AS, Gage FH, Weissman IL: Direct isolation of human central nervous system stem cells. Proc Natl Acad Sci U S A 2000;97:14720-5.

17 Kratz-Albers K, Zuhlsdorp M, Leo R, Berdel WL, Buchner T, Serve H: Expression of a AC133, a novel stem cell marker, on human leukemic blasts lacking CD34-antigen and on a human CD34+ leukemic line:MUTZ-2. Blood 1998;92:4485-7.

18 Waller CF, Martens UM, Lange W: Philadelphia chromosome-positive cells are equally distributed in $\mathrm{AC} 133+$ and $\mathrm{AC} 133$ - fractions of CD34+ peripheral blood progenitor cells from patients with CML. Leukemia 1999;13:1466-7.

19 Fauth F, Weidmann E, Martin H, Schneider B, Sonnhoff S, Hoelzer D: AC133 expression on acute myeloid leukemia blasts: correlation to FAB and to CD34 expression and possible implications for peripheral blood progenitor cell purging in AML. Leuk Res 2001;25:191-6.

20 Baersch G, Baumann M, Ritter J, Jurgens H, Vormoor J: Expression of AC133 and CD117 on candidate normal stem cell populations in childhood B-cell precursor acute lymphoblastic leukaemia. $\mathrm{Br}$ J Haematol 1999;107:572-80.

21 Buhring HJ, Seiffert M, Marxer A, Weiss B, Faul C, Kanz L, Brugger W: AC133 antigen expression is not restricted to acute myeloid leukemia blasts but is also found on acute lymphoid leukemia blasts and on a subset of CD34+ B-cell precursors. Blood 1999;94:832-3.

22 Green CL, Loken M, Buck D, Deeg HJ: Discordant expression of AC133 and AC141 in patients with myelodysplastic syndrome (MDS) and acute myelogeneous leukemia (AML). Leukemia 2000;14: $770-2$.
23 Kondo T, Hayashi M, Takeshita K, Numaguchi Y, Kobayashi K, Ino S, Inden Y, Murohara T: Smoking cessation rapidly increases circulating progenitor cells in peripheral blood in chronic smokers. Arterioscler Thromb Vasc Biol 2004;24:1442-7.

24 Hong SH, Nah HY, Lee YJ, Lee JW, Park JH, Kim SJ, Lee JB, Yoon HS, Kim CH: Expression of estrogen receptor-alpha and -beta, glucocorticoid receptor, and progesterone receptor genes in human embryonic stem cells and embryoid bodies. Mol Cells 2004:18:320-5.

25 Brannvall K, Korhonen L, Lindholm D: Estrogenreceptor-dependent regulation of neural stem cell proliferation and differentiation. Mol Cell Neurosci 2002;21:512-20.

26 Pulsipher MA, Levine JE, Hayashi RJ, Chan KW, Anderson P, Duerst R, Osunkwo I, Fisher V, Horn B, Grupp SA: Safety and efficacy of allogeneic PBSC collection in normal pediatric donors: the pediatric blood and marrow transplant consortium experience (PBMTC) 1996-2003. Bone Marrow Transplant 2005;35:361-7.

27 Shaffer RG, Greene S, Arshi A, Supple G, Bantly A, Moore JS, Mohler ER 3rd: Flow cytometric measurement of circulating endothelial cells: the effect of age and peripheral arterial disease on baseline levels of mature and progenitor populations. Cytometry B Clin Cytom 2006;70:56-62.

28 Tao J, Wang Y, Yang Z, Tu C, Xu MG, Wang JM: Circulating endothelial progenitor cell deficiency contributes to impaired arterial elasticity in persons of advancing age. J Hum Hypertens 2006;20:490-5.

29 Heiss C, Keymel S, Niesler U, Ziemann J, Kelm M, Kalka C: Impaired progenitor cell activity in agerelated endothelial dysfunction. J Am Coll Cardiol 2005;45:1441-8.

30 Hill JM, Zalos G, Halcox JP, Schenke WH, Waclawiw MA, Quyyumi AA, Finkel T: Circulating endothelial progenitor cells, vascular function, and cardiovascular risk. N Engl J Med 2003;348:593600.

\$3 Chen MC, Yip HK, Chen CJ, Yang CH, Wu CJ, Cheng CI, Chen YH, Chai HT, Lee CP, Chang HW: No age-related change in circulating endothelial progenitor cells in healthy subjects. Int Heart J 2006;47:95-105.

32 Moresi R, Tesei S, Costarelli L, Viticchi C, Stecconi R, Bernardini G, Provinciali M: Age- and genderrelated alterations of the number and clonogenic capacity of circulating CD34+ progenitor cells. Biogerontology 2005;6:185-92.

33 Egusa Y, Fujiwara Y, Syahruddin E, Isobe T, Yamakido M: Effect of age on human peripheral blood stem cells. Oncol Rep 1998;5:397-400. 